\title{
GESTOS ARTÍSTICOS E NARRATIVAS PÓS-MEMORIAIS: INTERROGAÇÕES PÓS-COLONIAIS EM PORTUGUÊS'
}

\author{
ARTISTIC GESTURES AND POST- \\ MEMORIAL NARRATIVES: POST-COLONIAL \\ INTERROGATIONS IN PORTUGUESE
}

Margarida Calafate Ribeiro

Fátima da Cruz Rodrigues

\section{RESUMO}

Este artigo oferece as narrativas biográficas de três artistas cujos trabalhos exercem um questionamento pós-memorial sobre o passado colonial português e as suas sombras no presente: Jorge Andrade, ator e encenador, nascido em Moçambique; Délio Jasse, artista visual, nascido em Angola; Vanessa Fernandes, cineasta, nascida na Guiné-Bissau. O nosso ponto de partida assenta numa reconceptualização do conceito de pós-memória desenvolvido no âmbito do projeto Memoirs - Filhos de Império e Pós-Memórias Europeias, que identifica a herança colonial como uma questão transversal para a definição da Europa contemporânea. O nosso objetivo é o de proporcionar narrativas biográficas que permitam refletir sobre o impacto do final do colonialismo português nas memórias, nas vidas e nas produções artísticas de uma geração herdeira da experiência dos processos de descolonização de territórios colonizados por Portugal.

PALAVRAS-CHAVE: Pós-memória. Narrativas biográficas. Arte. Pós-colonialismos.

\section{ABSTRACT}

This article offers the biographical narratives of three artists whose works post-memorially question Portugal's colonial past and its shadows in the present: Jorge Andrade, actor and director, born in Mozambique; Délio Jasse, 
artist, born in Angola; Vanessa Fernandes, filmmaker, born in Guinea-Bissau. Our starting point is based on a reconceptualization of the concept of post-memory developed within the scope of the project Memoirs - Children of Empire and European Post-Memories, which identifies colonial heritage as a transversal issue to define contemporary Europe. Our goal is to provide biographical narratives that allow us to reflect on the impact of the end of Portuguese colonialism on the memories, lives and artistic productions of the generation heir to the experience of the processes of decolonization of territories colonized by Portugal.

KEYWORDS: Post-memory. Biographical narratives. Art. Post-colonialisms.

Nas discussões contemporâneas sobre as heranças coloniais europeias, a história, a memória e a pós-memória adquiriram maior relevância política. A discussão atual sobre estas heranças no espaço público, museus, currículos escolares, média, a consolidação das diásporas africanas na Europa e sua discussão sobre o racismo estrutural, as pressões da migração e o surgimento de uma nova e cosmopolita produção artística, constituem um conjunto de elementos que apresentam questões complexas, que exigem novas respostas. O impacto destes debates na história e identidade europeias continua a ser uma lacuna para uma memória europeia verdadeiramente transnacional.

O projeto Memoirs - Filhos de Império e Pós-Memórias Europeias, financiado pelo Conselho Europeu de Investigação e coordenado por Margarida Calafate Ribeiro, no Centro de Estudos Sociais da Universidade de Coimbra, é um projeto sobre a diversidade europeia que identifica a herança colonial como uma questão transversal determinante para a definição da Europa contemporânea em si mesma e no mundo. Assenta numa reconceptualização do conceito de pós-memória como apropriação por uma segunda geração do capital de experiência, nomeadamente, de experiência traumática, de uma geração anterior que viveu os processos de descolonização de territórios colonizados por Portugal, França e Bélgica onde ecoam memórias de Angola, Moçambique, Guiné Bissau, São Tomé e Príncipe, Cabo Verde, Argélia e Congo.

Debruça-se, portanto, sobre os filhos, as suas memórias ou pós-memórias, as novas identidades europeias no pós-descolonizações: filhos de repatriados, de pieds noirs, de retornados, de ex-combatentes das guerras coloniais, de ex-colonizadores, de ex-colonizados, de refugiados. Como se deu a transferência de memória intergeracional relativamente ao processo do final do colonialismo europeu? Como é que esta memória se manifesta social e culturalmente hoje na Europa? Qual é o impacto dessa memória, muitas vezes latente, na Europa dos dias de hoje? 
Nesse sentido, o projeto desenvolveu investigação pioneira sobre o impacto das heranças coloniais nas gerações seguintes, ou seja, naqueles sujeitos que já não viveram os processos das guerras coloniais e das descolonizações, mas que, através das memórias familiares e públicas. os herdaram e que hoje os questionam, transformando, muitas vezes, essas heranças e interrogações em gestos artísticos. Trata-se de um conjunto de pessoas muito diverso que tem uma herança comum - viram as vidas dos seus pais atravessadas por um momento da história extremamente marcante pela revolução que introduziu nas suas vidas, na configuração dos seus países e das suas identidades - sobre a qual produziram as mais diversas narrativas e memórias. O que nos interessa reter nas conceptualizações referidas é, por um lado, a relação intergeracional que subjaz a esta memória dos descendentes e a questão da transmissão e da herança; e, por outro lado, a ligação que esta memória familiar, profunda e fundadora de um indivíduo, encontra com as memórias públicas e com as suas experiências presentes hoje como cidadãos ou artistas europeus. A partir de entrevistas e da análise de produções artísticas, examinamos a presença destas memórias mediadas, dos seus silêncios, e das suas interrogações, ou seja, do lado subjetivo da história, seja na experiência quotidiana, seja através das múltiplas e diversas narrativas que têm vindo a surgir sobretudo a partir dos anos 2000, nos campos da literatura, cinema, música, artes performativas e artes visuais. É de facto, no início do milénio, que começamos a assistir à emergência de uma outra performance artística mediada por estas memórias coloniais transmitidas ou silenciadas, em que os atores principais não são mais aqueles que as protagonizaram e que delas deram testemunhos traumatizados, alimentados pela imaginação de um impossível retorno, mas daqueles que receberam as histórias do colonialismo, da guerra e da descolonização como herança, aqueles que nasceram envoltos nestas narrativas mais ou menos fantasmáticas de uma história familiar outra, num lugar outro, onde se passou ora uma parte substantiva da vida dos seus pais, ora do seu pai ou familiares próximos como militares em contexto de guerra. Trata-se, portanto, de uma geração muito diversa de filhos destes antigos impérios, para quem esta história é já uma representação e que a reinterrogam não apenas enquanto evento passado que na sua micro-história desenha a história familiar, mas nas suas projeções no presente, procurando genuinamente conhecer uma história outra, relativa às origens dos seus pais, e, como eles, do seu país. Esta interrogação é a pós-memória. Pelos temas, pelas suas expressões e novas linguagens, a sua ação tem vindo a diversificar o debate europeu, a partir de uma perspetiva cosmopolita, transnacional e transterritorial, a renovar a literatura e arte europeia e a densificar as formas de intervenção individual e coletiva. Resumindo a pós-memória colocano espaço público político, social, monumental e edificado novas questões, essenciais para a construção de uma democracia com memória. Hoje, o que vemos não é, portanto, o regresso do passado colonial, ligado a mitologias de regresso, mas o início do debate entre esse tempo marcado pela dominação colonial e as relações sociais contemporâneas em sociedades herdeiras desses passados coloniais 
na Europa. Assim a abordagem que fazemos da controversa categoria da pós-memória não se encerra no seu aspeto teórico, mas é sobretudo analisada como uma preocupação pública em relação ao passado colonial europeu e as suas erupções no nosso presente. Protagonizados pelas gerações seguintes, ou seja, pelos herdeiros desse passado colonial europeu, a maioria das vezes sem memória própria desse tempo que já não viveram, estes são os debates e são eles que hoje tomam a palavra.

Neste artigo, situamo-nos no contexto português e passamos a palavra a três artistas, que generosamente nos concederam o seu tempo e as suas histórias e cujos trabalhos exercem um questionamento pós-memorial sobre estes passados e as suas sombras no presente: Jorge Andrade, ator e encenador, nascido em Moçambique e involuntário protagonista do movimento de "retorno" a Portugal, na pós-descolonização, que na peça Moçambique imagina a sua vida se os seus pais tivessem ficado no Moçambique socialista; Délio Jasse, artista visual, nascido em Angola e protagonista de um dos mais originais e questionadores trabalhos sobre arquivos fotográficos coloniais privados e sobre um Portugal e uma Europa pós-migratória; Vanessa Fernandes, cineasta, nascida na Guiné-Bissau, cujo segundo filme interroga a permanência do racismo na sociedade portuguesa pela presença fantasmática do império e das figuras do ex-colonizador e do ex-colonizado.

\section{DÉLIO JASSE}

\section{"Chamo-me Délio da Silva".}

"De onde é que vens? Por quanto tempo ficas? E quanto é que trazes?"

Délio da Silva, não é um nome grego, não é um nome alemão, mas simplesmente português, o meu bisavô era português, os meus avós estavam em Portugal. Foi assim que cheguei a Portugal, vindo de Angola, onde nasci. Foi no dia 20 de dezembro de 1999, eu tinha 18 anos. Foi um momento muito forte, marcado por esta linha de separação. Até que ligaram para a minha avó para saber se era mesmo a minha avó. Foi um choque ligarem para a minha avó, que felizmente estava em casa e o meu avô tinha posses, tinha uma casa própria. "Quanto é que trazem?", “Ah, 600 euros”. Na altura, havia travel check. E nós tínhamos um travel check, com uma quantia elevada, como se viéssemos de férias. Depois foi levar o carimbo no meu passaporte, sem saber bem se estava a entrar ou não. E, até hoje, tenho esse sentimento de insegurança com as fronteiras e os carimbos nas minhas entradas. Hoje como artista trabalho sobre isso. Trabalho sobre as linhas que definem que tu estás aqui, e ali estou eu. É a fronteira, os documentos que nos definem, os carimbos que nos autorizam.

Foi essa a minha primeira experiência em Portugal, com um indivíduo dentro de uma cápsula a carimbar os meus documentos e a perguntar quanto é que trazia. Eu era um miúdo, era a primeira vez que viajava, 
estava nervoso, estava a fugir de uma situação delicada, tinha medo de não conseguir entrar. E depois do sacrifício que os meus pais tinham feito, para poder mandar dois filhos para Portugal, para nos salvar de ir para a guerra, porque era isso que acontecia aos jovens angolanos. Esta receção foi muito marcante. Vivemos situações muito aterrorizadoras em Angola, com a guerra em Luanda, lembro-me de tudo. Foi muito traumatizante, eu deveria ter 11, 12 anos e os meus pais tinham essa preocupação. Pouco tempo mais tarde, saiu o meu irmão mais novo. Eu tinha consciência de que era muito importante conseguir entrar e, por isso, toda esta situação na fronteira foi muito, muito, muito, dura, muito séria. $\mathrm{E}$ depois as malas não vieram e a minha mala era tudo o que eu tinha.

Fui acolhido inicialmente pelos meus avós que, na altura, estavam cá, a minha tia mais nova e os meus primos. E foram-me arranjando coisas, casaco, telefone, uma série de objetos, uma série de pequenas coisas que me marcaram muito naquele fim de ano, que era o meu aniversário e em que entrámos para outro milénio.

Estive sempre com o meu irmão mais velho nessa caminhada, andamos por vários sítios, fiz a matrícula na escola, para continuar os estudos e tinha de procurar um emprego para pagar o nosso quartinho na Damaia, numa zona ao pé da tia, mas muito tranquila. $\mathrm{O}$ meu primeiro emprego foi na construção civil. Era o que havia, sem documentos, não havia outra alternativa. Em Caneças, Odivelas, lá para cima, no Montefrio. O trabalho na construção civil é muito duro, é pesado carregar 20, 40 litros de balde de massa.... Éramos todos miúdos e tornou-se um trabalho coletivo. Afinal tinha vindo para Portugal fazer uma espécie de serviço militar, mas sem guerra.

Os meus pais tinham-me dado uma boa formação, mas sem documentos não tinha alternativas. E Portugal estava a construir muito, a ponte Vasco da Gama, depois da Expo 98. Ganhava-se bem, mas foi muito duro, tive que crescer rápido, e aprender a lidar com a situação de imigrante na pele. Mas eu não era um imigrante: o meu bisavô era português, português é a minha língua materna. O que é que é ser imigrante? Isso são sempre questões que se me colocavam e que hoje no meu trabalho trato muito.

Até que fui para um atelier de serigrafia de um primo meu, filho de um tio que tinha ido para Portugal nos anos 70 e abriu o atelier. Trabalhou com vários artistas: Paula Rego, Gracinda Candeias, Kiki Lima, e Malangatana. É neste momento que começa a minha mudança, começa a minha escola, o meu contacto com artistas, com a arte a acontecer e dediquei-me muito, estudei muito.

Foi aqui também que tive o meu contrato de trabalho, o que me permitiu iniciar os episódios da legalização com os vistos. Ao fim de cinco ou seis anos, conseguia-se a autorização de permanência, ainda provisória, e depois o cartão de identidade azul, o passaporte. Digo episódios porque estes processos são muito longos e muito desmoralizantes. Foram vivências que me marcaram muito desde a entrada em Portugal. $\mathrm{O}$ meu processo nunca 
estava terminado, faltava sempre alguma coisa e isso cria uma insegurança, uma vulnerabilidade, não podia circular, não podia viajar. Claro que acabei por o fazer, com os esquemas possíveis que todas as pessoas nestas situações têm de usar, e que nos criam uma noção de inexistência, de falsidade sem culpa, muito perturbadora, que nos faz perder a identidade, que nos faz estar sempre a simular. Eu tinha medo que acontecesse isso, tinha medo de me esquecer quem era, quando nasci, como me chamava.

Até que, mais uma vez, já de forma dramática, reuni de novo todos os documentos e acabei por fazer um escândalo. A minha companheira, que é italiana, também já desacreditava da seriedade do processo, até que a senhora da repartição, numa expressão que eu não me esqueço, disse: "Ah, então dá-me os documentos todos, e agora vou tentar". E finalmente consegui. Passado um mês estava legalizado ao fim de dez anos de espera. $\mathrm{O}$ meu trabalho Schengen, deste mesmo ano, coloca essa questão. Quem pode ser do espaço Schengen? E ainda hoje trabalho obsessivamente fronteiras, números, carimbos e documentos. Tenho dois ou três passaportes e não tenho um lugar específico no mapa, "eu sou, venho daqui, sou dali".

Eu nasci em Angola, mas não me sinto 100\% angolano, nem me sinto $100 \%$ português, nem $100 \%$ italiano, desde que vivo em Itália. E donde venho? O meu bisavô da parte paterna era moçambicano, foi enviado para Angola como preso político. Palege, não é angolano, é moçambicano. Da parte materna era português, do Norte, da Silva é muito tuga, é muito português, não é angolano. Em Itália, onde vivo, eu sou da Silva, não sou Jasse. É pelo nome que tudo começa e a história vai-se metendo pelo meio. Tenho um tio, irmão da minha mãe, que esteve no exército colonial português no tempo da guerra colonial e tinha uma madrinha de guerra, que lhe escrevia cartas e aerogramas; e tenho um outro tio que esteve do lado da guerra de libertação. Gosto de desmontar os nomes, de desmontar as histórias e, ao fazê-lo, acabo por criar peças, a partir dos nomes, das identidades, dos documentos. Sou um grande colecionador: tenho 200 aerogramas, cartas, fotografias antigas de família, em que me revejo, passaportes de vários países. Coleciono passaportes portugueses dos anos 50, documentos de Cabo Verde, Moçambique, Angola, coisas que encontro ou que vou comprando na Feira da Ladra, que é a minha grande biblioteca informal. Aprendo muito, encontro material, falo com as pessoas, como a D. Amélia que é de Benguela.

Interessa-me, através do meu trabalho, poder dar continuidade a estes documentos, a esse arquivo morto, mas que, na verdade, não está morto, está vivo. Interessa-me essa parte da história de Angola, de Moçambique que é a vida colonial. Eu cresci na casa do colono, nas casas que foram ocupadas depois da saída dos portugueses em Luanda.

Interessa-me a história dessas pessoas, o que faziam, o que pensavam, como viviam, e gosto de trabalhar sobre essas fotografias, sobre as ocupações, sobre os equipamentos que foram construídos no tempo dos portugueses, como os cinemas ao ar livre, o Avis que na minha época era 
Karl Marx, e onde vi tantos espetáculos e filmes e agora está todo degradado. Um dia entrei pelo cinema a fotografar, arrepiava-me, caiam-me as lágrimas, de ver aquilo num cinema em que em miúdo quando entrava era um sonho que se abria. E o Miramar que é um cinema lindíssimo. Há em Angola obras que não há em Portugal. Experimentou-se muito em Angola e funcionou, mas não demos continuidade. Eu cresci na casa de um colono, de que me recordo, pegada por pegada. Recordo-me também de um baú muito antigo, uma mesinha de cabeceira, deixada pelo colono. Quando os portugueses saíram, deixaram as casas e as pessoas ocuparam, pessoas que, de repente, ficaram com o cão, com o carro, com a casa do antigo patrão. Lembro-me de um Alfa Romeu, um Fiat, um Mini Austin no quintal que era enorme. E muitos angolanos deixaram o quarto do quintal, os anexos e passaram a ter tudo. É uma súbita ocupação de espaço.

A minha série The lost chapter Nampula-1963 é feita a partir de fotografias da vida dos colonos em Moçambique, que era o país do meu bisavô moçambicano Palege Jasse. Sempre ouvi essas histórias. E quando vou ao Prenda, que é uma zona que era o Morro da Baiana, como se chamava na altura, estou na casa do meu bisavô moçambicano, que veio parar a Angola, como preso político, e nunca mais voltou. Foi o meu bisavô moçambicano que ocupou aquele terreno, e construiu a casa. É lá que tudo começa, e eu vou fotografar e aparecem nas minhas imagens, a casa, na verdade, várias casas, cinco ou seis casas, que até hoje existem. Moçambique. Eu não tenho informação nenhuma de Moçambique, conheço alguns artistas de Moçambique. E quando ando à procura desta história do meu bisavô, vem-me parar às mãos esse arquivo de Moçambique, Nampula 63. O que é que faço? E começo a trabalhar, a pesquisar, a construir o arquivo com a sua ordem, as suas técnicas. E comecei todo o processo de desmontar o trabalho: pus-me na condição de moçambicano, e assim o meu bisavô moçambicano tem uma casa. Era um senhor enfermeiro, que segundo contam andava de Mercedes em Luanda, nos anos 60. Trabalhava com os portugueses, era um angolano assimilado. E começo a história da família, dos seus filhos, da minha tia que teria sido a primeira hospedeira da TAP negra. Começo a desmontar o arquivo que dará origem a, The lost chapter Nampula-1963 tendo, portanto, uma referência de família em que a imagem ganha uma identidade própria e gera uma direção. E vou elaborando o trabalho, criando um apagamento de uma memória suspensa ou que desaparece porque as figuras, as caras, são quase apagadas. Em algumas imagens, por exemplo vê-se a cabeça das pessoas muito suspensa, mas não se vê o corpo, quase uma nuvem. Não é que esteja a desaparecer, ao contrário, estou no processo de fixar a imagem. Depois vem essa coisa da imagem latente do processo fotográfico, e a imagem, em si, que já é forte, mostra uma Angola, um Moçambique que não parece Moçambique, parece Portugal, em que tudo é transformado e não se vê nenhum negro, vê-se toda a gente de fato, de cachecol. E com grandes bebidas, cigarros, estão todos juntos numa mesa, sentados, a brindarem, com o candeeiro abajur, com uma cortina, candelabros, tudo muito bonito, 
e está uma senhora toda bem vestida ao pé. Para completar o que quero contar, vem a estética, de dentro dos parâmetros que eu gosto. São, portanto, histórias envolvidas que fazem parte de nós, sem, contudo, recusar a violência que as relações, que constroem estas imagens, contêm. Ela está lá na invisibilidade/visibilidade com que jogo. Quando estava a preparar esta exposição, a minha amiga Livia Apa, deu-me o Caderno de memórias coloniais da Isabela Figueiredo, que é um livro fortíssimo, ela conta aquilo muito bem, muito bem. Eu não vivi nada daquilo, mas só de acompanhar o texto, construía as imagens... Ela esquece a filha do colono, tem um olhar incrível. É muito interessante, muito bem elaborado, muito bem feito.

Um outro trabalho a partir de arquivos é Nova Lisboa, que era o nome colonial da atual Huambo. Era um espaço muito organizado, uma arquitetura muito bonita, como o Hotel África, como diz nas fotografias, e que hoje está todo degradado, completamente destruído. São fotografias muito bonitas. Com Nova Lisboa fiz uma coisa muito bem feita para Angola, na onda de Nampula 63. São imagens muito fortes da vida dos portugueses naquela cidade. Lembro-me do senhor que me vendeu este arquivo, são imensas fotografias. Falei com ele.

Nós chamámos a geração dos "tinhas". "Eu tinha, eu tinha uma casa” que tinha isto, tinha aquilo. Perderam muito. É verdade. São fotografias muito bonitas, muitas vezes tiradas por um fotógrafo contratado em dias de festa, e interessa-me captar esse olhar, o negro sempre distante, em posições de serviço, em segundo plano. Trabalho sobre isso: realço o negro e dou aos protagonistas uma identidade suspensa, desmonto as imagens e contextualizo. A partir destas fotografias, destes documentos consigo ver algumas falhas, alguns fantasmas também, e construo novas histórias.

Interessa-me também a chegada destas pessoas. Tive um colega de trabalho, bem mais velho, que tinha nascido em Benguela, no Lobito, que me dizia "Eu sou angolano, eu sou angolano." Foi ele que me foi dando estas informações. Vi fotografias do pai dele com um camião, pois ele tinha uma fazenda com trabalhadores. E contava-me histórias de Benguela. Quando vou a Portugal, almoçamos juntos, e conta-me sobre a chegada a Portugal, como o dinheiro não valia nada e muita coisa que ficou na alfândega. É uma narrativa que me lembra muito um filme muito bonito De armas e bagagens.

Tudo isto é uma parte da nossa história e é importante que se dê continuidade à história. Portugal e Angola precisam deste arquivo, precisam de olhar esta história, que para mim são narrativas, séries de imagens a partir das quais trabalho criando outras imagens.

Não me interessa só fazer fotografia, interessa-me o lado estético. Interessa-me também muito o lado histórico: do passado de uma imagem, como a contextualizo, mas também o que é que esta imagem me diz ou me pode dizer hoje.

Cada imagem é fotografada e revelada por mim. Como se tivesse sido eu o fotógrafo, na altura, a olhar para a família inteira. Eu fotografo 
todas as imagens, vivo com estas imagens, com estes assuntos, mas não estão presentes, não sinto o cheiro, nem o clima. Capto no momento em que fotografo. E todas as imagens são reveladas e impressas por mim. Dou uma certa dignidade aos anónimos, conto uma história. E depois carimbo, certifico... Isso é muito importante.

Também me interessa a história da guerra. Ela está na minha família e interessa-me o diálogo entre as duas partes. É uma coisa muito curiosa, porque em Portugal não se falava, mas toda a gente tinha estado envolvida, toda a gente tem alguém que esteve nas colónias: a família veio de lá, um pai, um avô, um bisavô, um trisavô. Toda a gente. Basta entrar num táxi e a seguir à tradicional pergunta - "De onde és?" Ou "És de Chelas", ou "És da Buraca", da "Cova da Moura", - segue-se "Eu estive em Angola, eu estive em África, eu estive na Guiné, eu também estive lá, eu sou de lá, eu sou de lá," "Eu fui militar lá". Eu tenho imagens de uma série o Além-Mar, por exemplo, que mostra essa ligação, porque, na altura, Salazar também obrigava os jovens a fazer o serviço militar em Angola. Eles nem sabiam para onde iam. Mas essa série tem imagens muito fortes. O que era aquilo, não é? Que guerra era aquela, o que é que eles fotografavam?

Em Portugal houve muitas histórias ocultadas e que não foram ultrapassadas ou questionadas. Essas histórias estão presentes nas pessoas que cruzamos em Portugal, mas também em Angola e em Moçambique. Estes arquivos são importantes para todos. Faz sentido mostrar em Portugal, mas Portugal já está mais habituado. Tenho visto muita coisa em Portugal, eu quero é mostrar em Angola, onde tudo é muito recente. São dois países que têm uma relação delicada, que precisa de ser trabalhada. Tenho feito coisas com a Alemanha, com a França, estou agora a dar aulas em Itália, na NABA, e tenho falado desta história colonial entre Portugal e Angola.

A relação Angola-Portugal é uma relação muito delicada, muito frágil, com muitas coisas que não são claras, mas é também uma relação muito forte, de mútua proteção desconfiada. Angola e Portugal é também uma história de família, de muitas famílias, todos temos alguma relação. Mas paradoxalmente quando um africano tem uma relação com uma portuguesa é muito complicado entrar na família, muito complicado. Há histórias de muito racismo. Mas Portugal está muito dentro de Angola e Angola em Portugal. Voltamos às fronteiras. O que é que mudou? Um europeu quer entrar num país africano, entra quase sem problema, o visto é dado à entrada, quer montar o seu negócio e monta-o. Estive em Bamako e de quem são os restaurantes? De franceses. Um africano quer entrar na Europa e a priori é uma barreira. Isso mostra-nos o que é ser europeu, e o que não é ser europeu.

Mas houve um passado, nós para estarmos cá é porque houve uma história de outros que estiveram lá. Schengen é esse corte radical com a história da Europa, fora da Europa. Há certas barreiras que têm de ser quebradas. Há artistas que abordam só um lado, há quem aborde o outro. Eu trabalho com os dois, e não estou nem de um lado, nem do outro. 
E rejeito muito a crítica esperada de que como sou africano tenho de fotografar "África”, os negros, etc. Eu comecei a fazer fotografia em Portugal e depois a fotografia "africana”. Uma Malick Sidibé ou Sambo Seydou Keita.... Eu não os vejo como a fotografia africana. Não existe fotografia europeia, não existe fotografia sul-americana. Existe a fotografia, e ponto final. É isso que eu faço.

A minha distância de Angola é importante, tudo vem muito daí. Também os meus pais e as minhas irmãs acabaram por sair, por ir para a Holanda, tiveram um exílio político, por um período de 3 anos. Estávamos todos dispersos. O meu irmão, em Roma com o meu tio, os meus pais na Holanda, eu e o meu irmão mais velho em Portugal. Todos dispersos, em situações muito diferentes. Esta situação desperta a memória, que é composta por imagens. É disso que vou à procura. Se for a Luanda, se estiver a fotografar em Luanda, porque há pouco arquivo, vou à procura de uma outra estética, de uma outra arquitetura. Tenho andado à volta da arquitetura racionalista que me permite, depois, olhando aquelas imagens, fazendo um close-up, me permite ver os meus pais, os meus avós numa Luanda diferente, numa outra Luanda, a entrar para os bairros que, hoje em dia, são quase guetos, mas em que havia as casas pré-fabricadas de madeira que já não se veem. Há uma casa de madeira que resistiu, cheia de coisas à volta, mas ainda é a base da estrutura de madeira onde alguns angolanos, que prestavam serviço na casa dos portugueses no centro de Luanda, estavam. Consigo visualizar o que era a vida antigamente. A transformação sucessiva mata a história, vai criando níveis de presença e de ausência, até poder deixar de haver informação. Vou atrás desses rastos: monumentos, pedaços da calçada portuguesa, casas, cinemas.

Angola é muito forte, é muito forte em mim. Tem qualquer coisa que me prende. Cada vez mais eu estou com a cabeça virada para Angola, e quero, quero que tudo corra bem para Angola, mas sei que se não estivesse fora, não conseguia fazer as coisas que faço.

Délio Jasse foi entrevistado por Margarida Calafate Ribeiro, em 12 de abril de 2018, na Universidade de Milão, Itália. Délio Jasse é artista visual. Agradecemos a Vincenzo Russo da Universidade de Milão o bom acolhimento e a colaboração.

Mais informação: http://deliojasse.com/ 


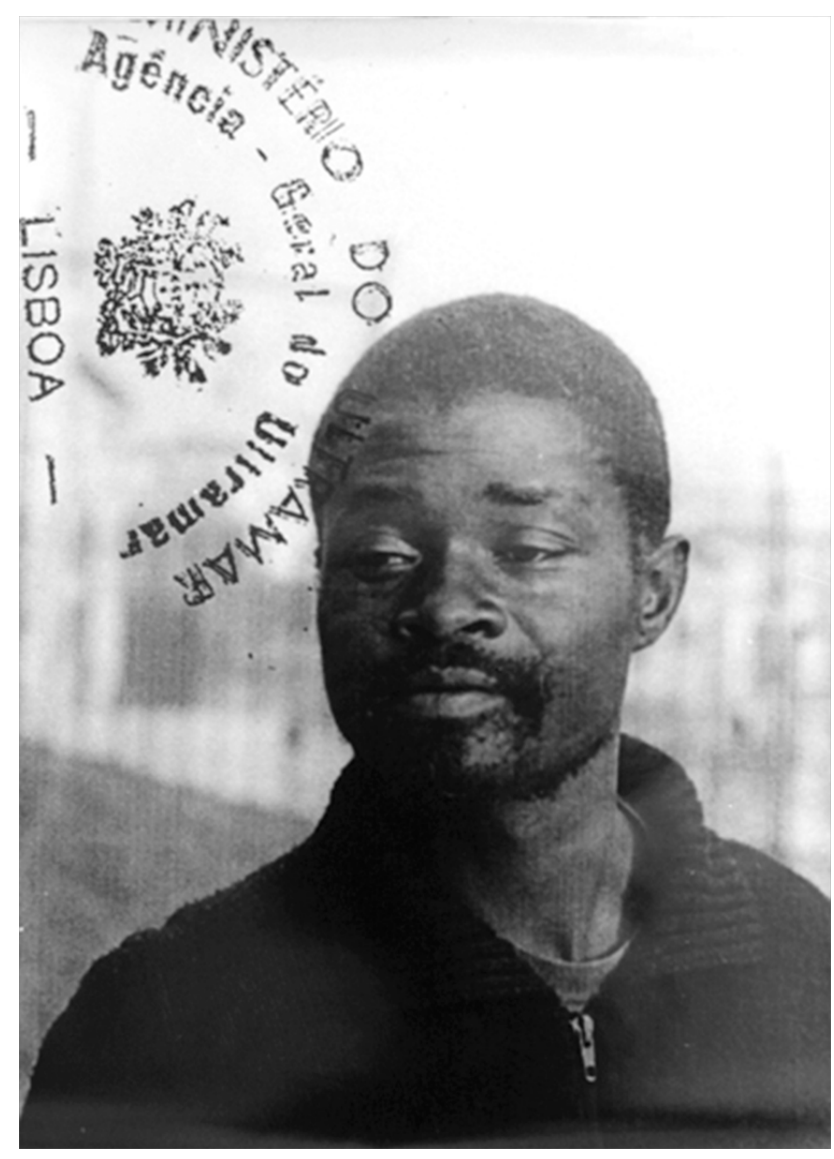

Imagem 1 - Série Schengen | 2010 | Délio Jasse (cortesia do artista).

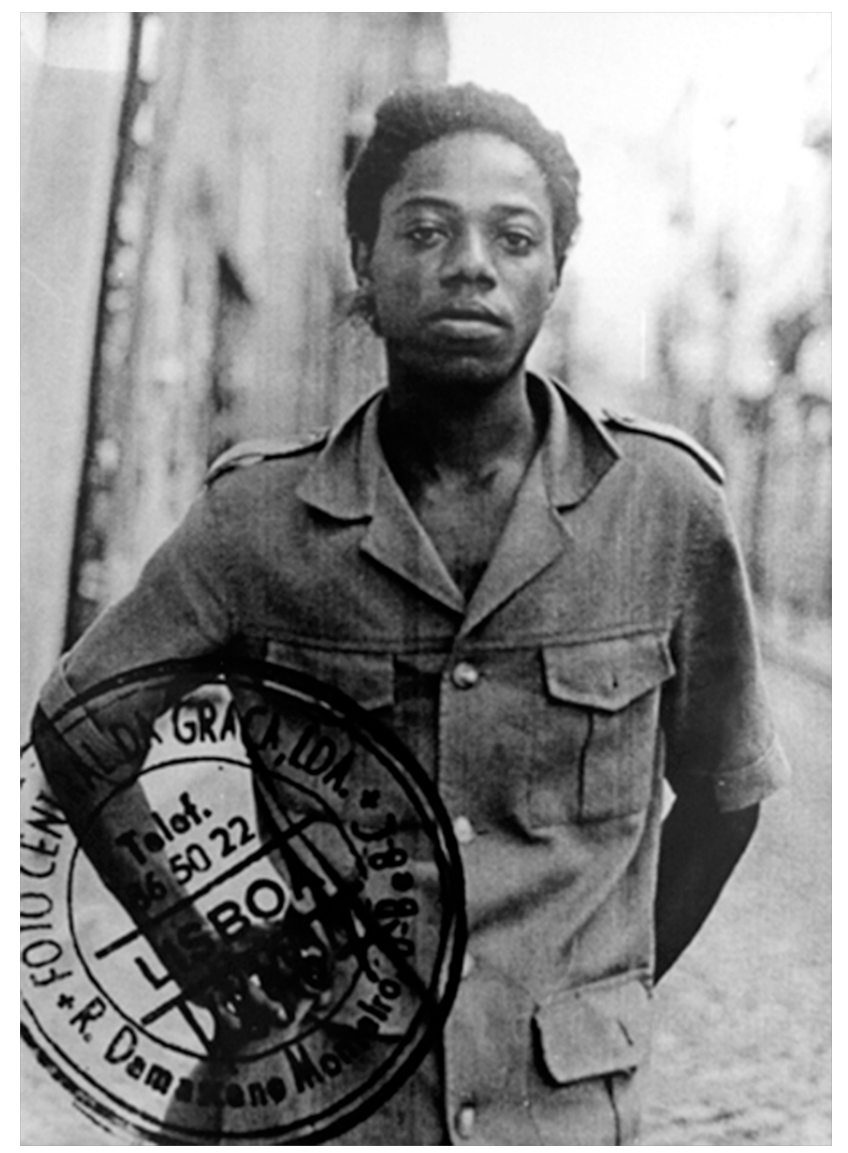

Imagem 2 - Série Schengen | 2010 | Délio Jasse (cortesia do artista). 


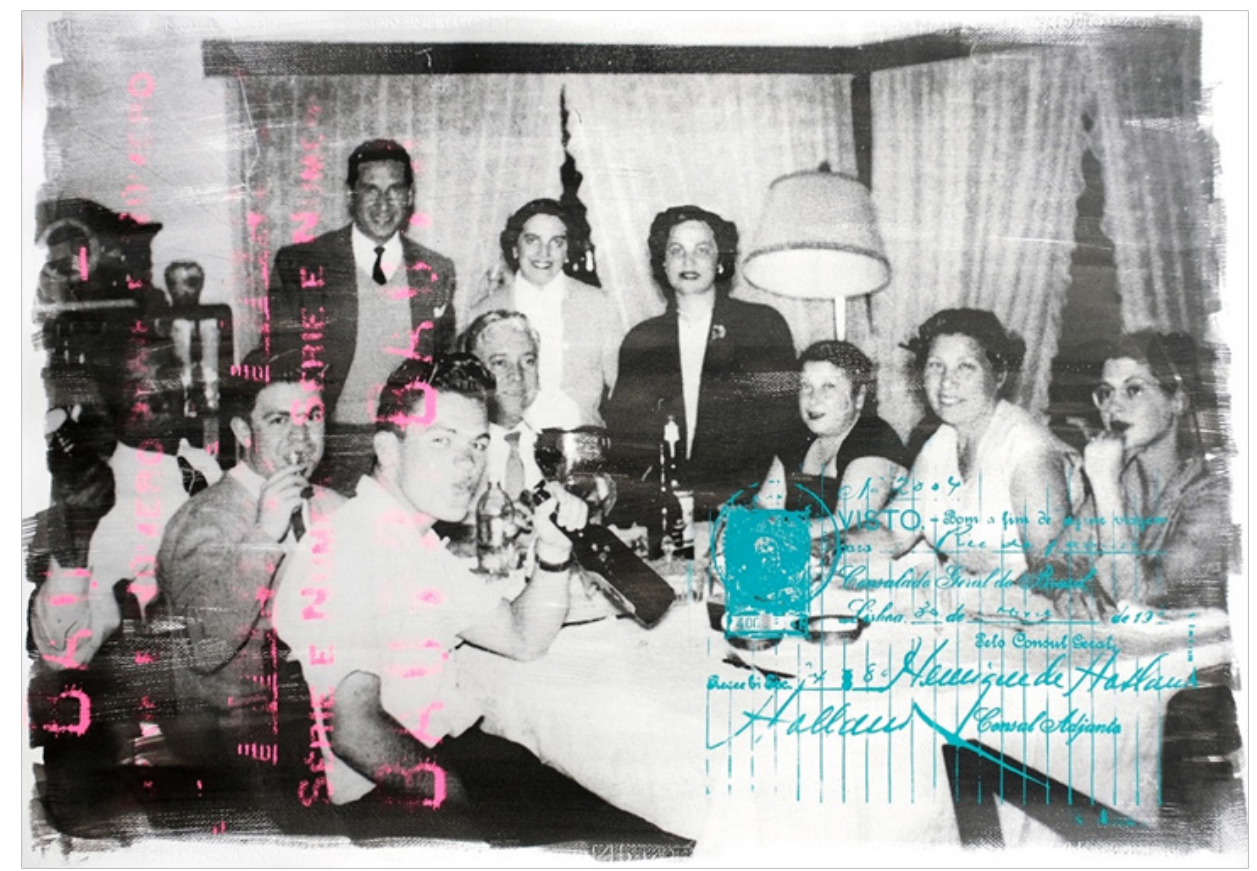

Imagem 3 - Série The lost chapter: Nampula 1963 | 2016 | Délio Jasse (cortesia do artista).

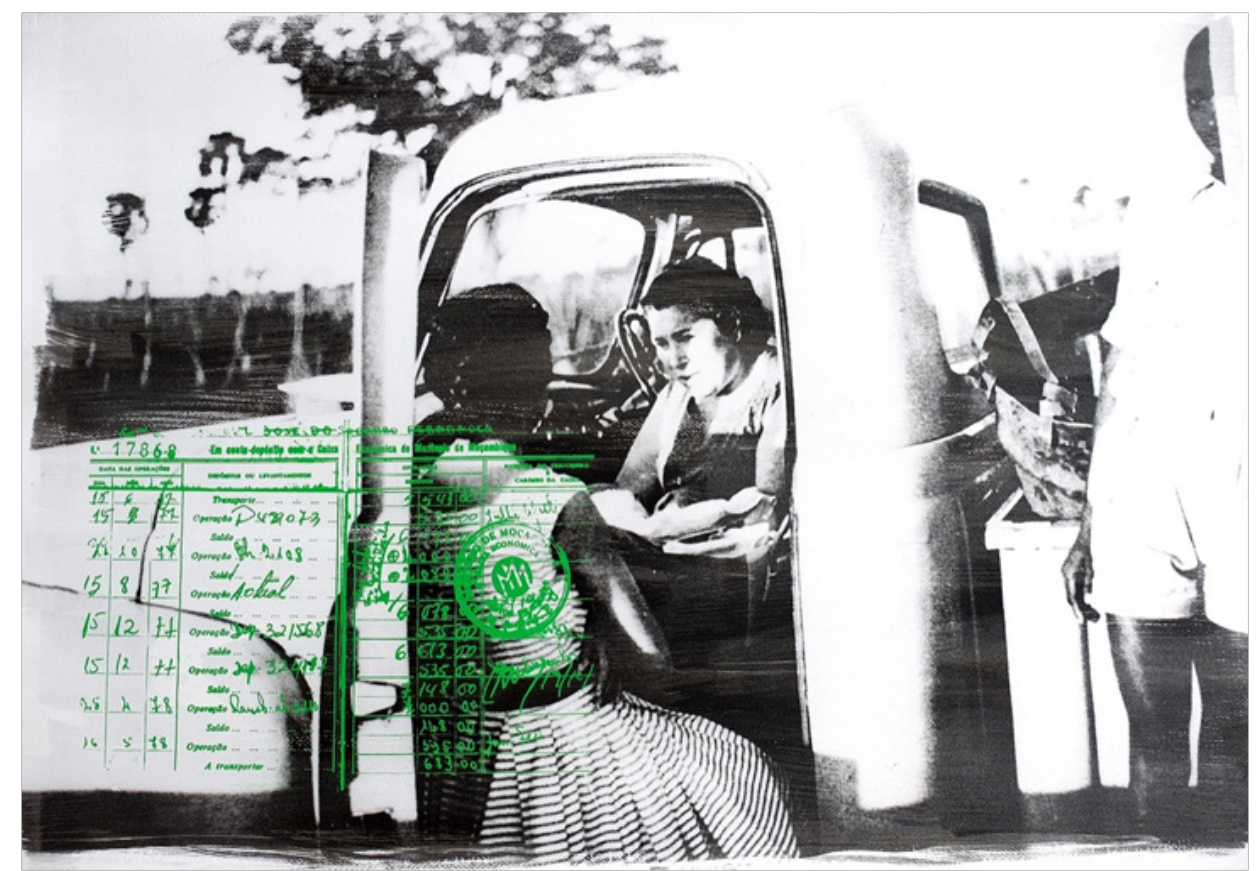

Imagem 4 - Série The lost chapter: Nampula 1963 | 2016 | Délio Jasse (cortesia do artista). 


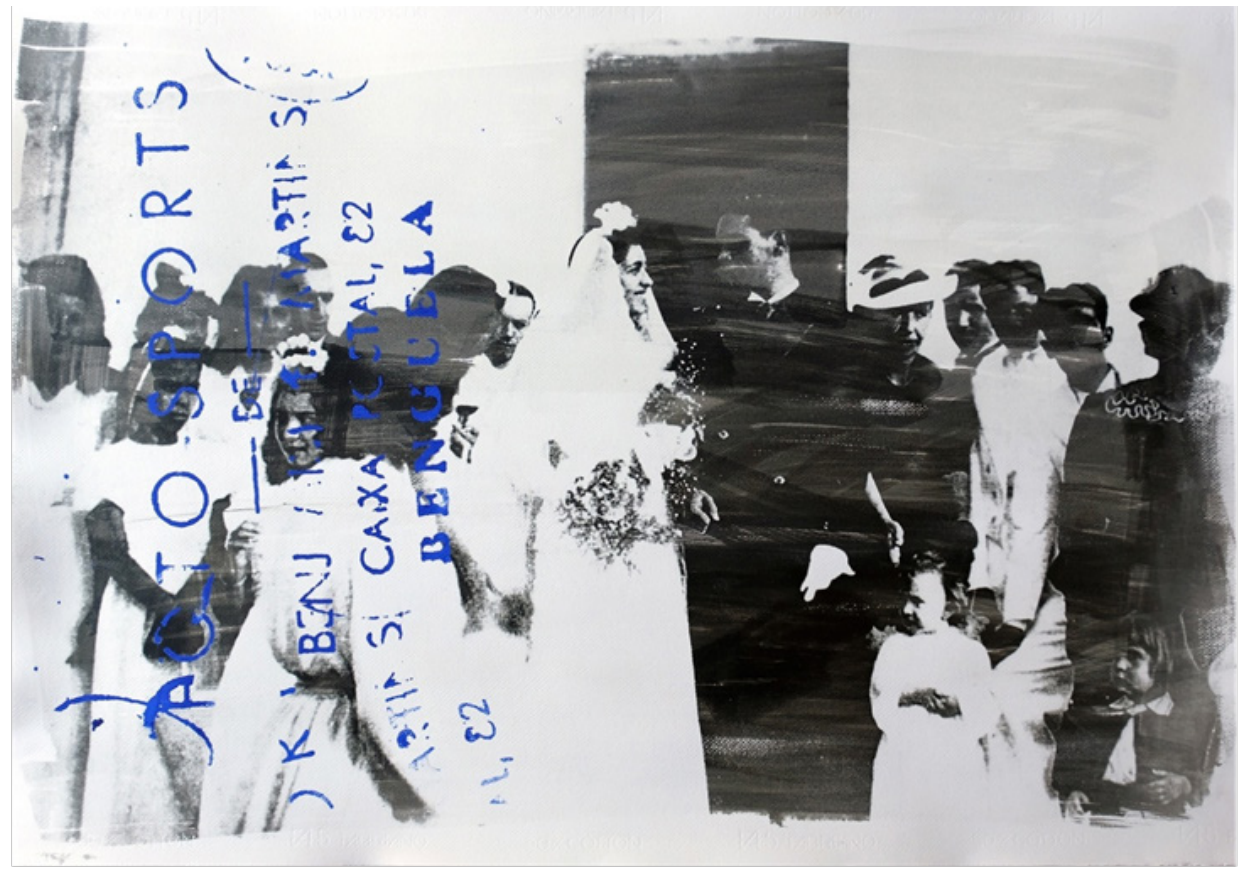

Imagem 5 - Série Nova Lisboa | 2018 | Délio Jasse (cortesia do artista).

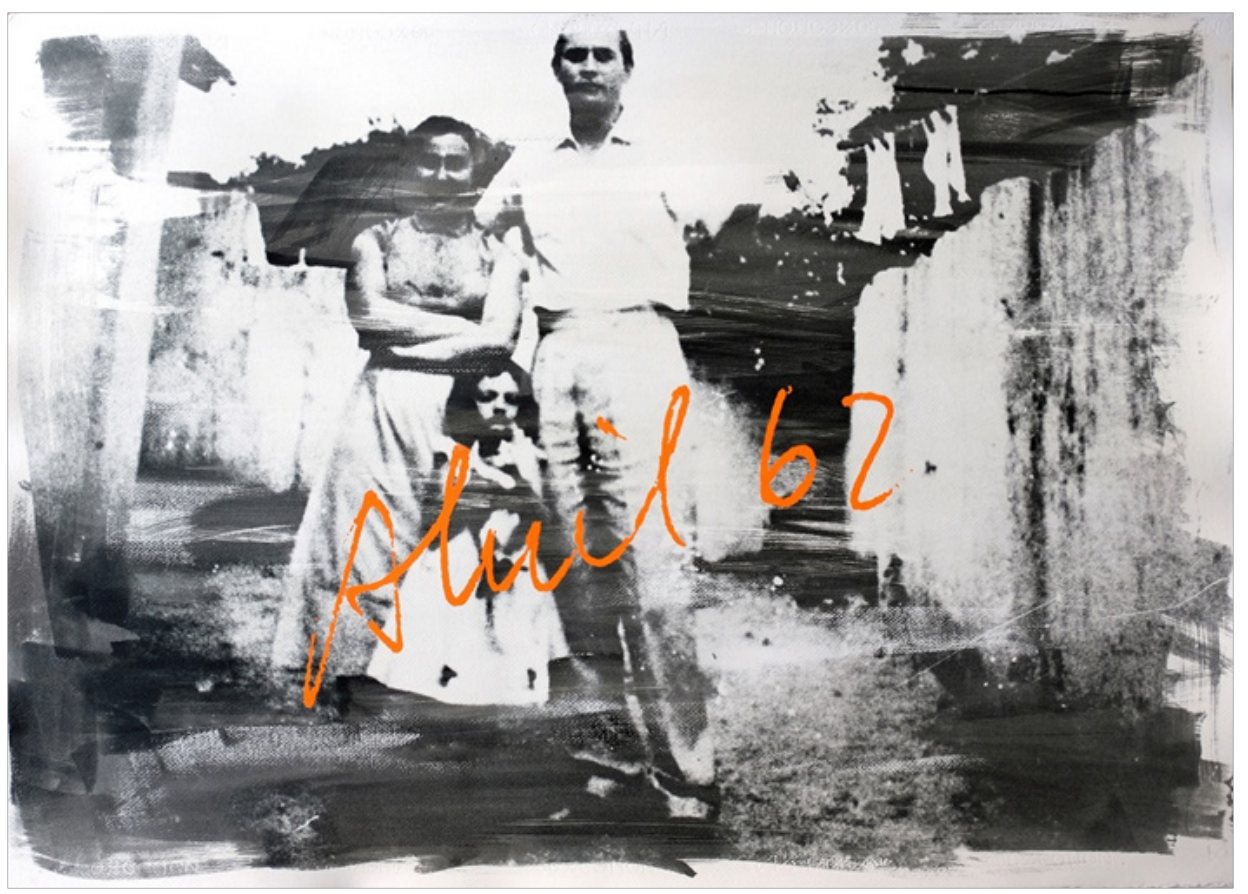

Imagem 6 - Série Nova Lisboa | 2018 | Délio Jasse (cortesia do artista). 


\section{“A grande aventura era Amílcar Cabral, não havia cá contos de fadas"}

O meu pai é cabo-verdiano e a minha mãe é guineense, filha de um goês e de uma guineense. Conheceram-se em Lisboa à volta dos estudos e das lutas, ligados aoPartido Africano para a Independência da Guiné e Cabo Verde (PAIGC). Com a independência da Guiné-Bissau, em Setembro de 1974, os meus pais voltaram para se engajarem na construção do país. Pouco tempo depois de eu nascer, em 1978, decidiram continuar os estudos em Paris, onde vivi sete anos, na região parisiense de Nanterre, no início dos anos 1980. Hoje é uma universidade, mas naquela altura era zona de emigrantes. A minha casa era uma casa de emigrantes, falava-se crioulo, ouvia-se música africana, discutia-se sobre todos os assuntos, havia um convívio bastante intercultural. Os meus pais tinham vivido a independência de forma muito intensa, tanto que o meu pai tinha começado Medicina e acabou por mudar para Antropologia. Era um tempo de intensa militância. A grande aventura era Amílcar Cabral, não havia cá contos de fadas.

Na escola falávamos francês, e eu não tinha muitos amigos, mas rapidamente consegui estar nas três línguas: o crioulo, o português e o francês. O meu pai formou-se em Antropologia e a minha mãe em Linguística, mas, entretanto, os meus pais separaram-se, e a minha mãe, com quem eu fiquei, foi viver para Macau, onde vivia a minha avó, que tinha acabado de perder o marido. Na verdade, não era a minha avó, era minha tia-avó, mas tinha sido com ela que a minha mãe tinha crescido. A mãe da minha mãe estava grávida de sete meses quando o seu marido teve um acidente e faleceu. Portanto, a minha mãe nunca conheceu o pai e foi a minha tia avó que tomou conta dela. Cresceu em Bissau, na época colonial, mas o meu tio-avô que era cabo-verdiano, efuncionário do Estado - era enfermeiro -, foi colocado em Macau, ou seja, foi deslocado para outra colónia, como era comum na administração portuguesa, e a minha mãe acabou por viver parte significativa da sua vida, praticamente todo o liceu, em Macau. Só quando foi para a universidade é que foi para Portugal, quando conhece o meu pai, que, ainda hoje, vive em Bissau.

É por esta relação anterior que eu, com oito anos, vou para Macau, que era um território familiar para a minha mãe, mas não para mim. A minha avó tinha crescido numa família abastada, e teve uma educação muito religiosa e muito portuguesa, o que a fazia entrar num discurso complexo de análise, pois ao mesmo tempo que defendia Salazar, sabia que a minha mãe tinha estado na luta anticolonial. Eu vinha de uma casa muito jovem e alegre em Paris e aquela era uma casa triste. A minha avó estava de luto, sempre vestida de preto, tinha perdido o marido há pouco tempo. Não se podia rir, não se podia falar de certas coisas, não se podia ouvir música, não 
se podia discutir ou ter ideias diferentes. É com a minha avó que a religião entra na minha vida e que começo a ter preocupações com o pecado e outros temas que vêm com o cristianismo, a que se liga, no caso da minha avó, uma educação e uma vida na Guiné sob o regime colonial. Isto vai gerar uma série de interferências entre as três gerações que habitam a casa. Macau foi duro, e a escola, no início, era um ambiente hostil. Não conseguia fazer amigos, não falava bem a língua, e acabei por sofrer uma série de processos de rejeição. Era uma escola portuguesa, com um curriculum português e eu percebia pouco, mas havia coisas muito diferentes da história dos meus pais. A minha mãe, que trabalhava na área cultural, tinha um olhar atento para me dar essa reinterpretação da história, explicava-me o subtexto, mas vivíamos numa colónia, no extremo Oriente, e havia uma postura colonialista, um pensamento, uma forma de ensinar que não questionava. A adaptação não foi fácil, pois há sempre alguém que nos lembra que somos diferentes. Lembro-me de naquele ambiente os meus colegas dizerem "Aí os chinocas", referindo-se aos chineses, e foi preciso eu ter um olhar crítico sobre mim mesma para tirar essa palavra e essas expressões do meu vocabulário, esse lado discriminatório. E isso também se refletiu sobre mim: começava pelo cabelo, estendia-se às próprias formas do meu corpo e à minha cor. Eu era a preta, e há um momento em que eu não sabia distinguir quando isso era dito com intenção de magoar ou se era carinhoso. Na primeira escola em que estive, enquanto não falava português corretamente, era bullying, eu percebia que não era por bem. Mas era uma escola muito diversa: havia macaenses, portugueses, havia duas irmãs angolanas, duas moçambicanas e depois tornamo-nos muito amigas. O que talvez me tenha marcado nestas andanças foi a viagem e estar sempre a adaptar-me, a construir um espaço. Eram espaços muito diversos, muitas pessoas diferentes, línguas, hábitos, culturas. E apesar de tudo foi muito bom ter percebido cedo que, se quiserem, as pessoas conseguem entender-se, independentemente da língua, da cor, das origens.

A minha imagem da Guiné, afinal onde eu tinha nascido, era isso mesmo, uma imagemconstruída a partir de imagens de livros e, sobretudo, das descrições da minha avó e da minha mãe. Eram narrativas muito romanceadas, mediadas pela distância também para elas, pois ambas tinham vivido muito tempo fora da Guiné. A minha avó contava-me sempre a mesma história da sua infância ou do casamento e descrevia Bissau de uma maneira encantada, com um brilho nos olhos e a minha mãe também. Quando finalmente fui a Bissau com a minha avó, teria 13 anos, primeiro tive um choque, tive de reajustar aquela paisagem com as imagens que eu tinha. Foi também o momento em que vi o meu pai depois de muitos anos sem o ver. Foi uma experiência muito marcante, pois, apesar de eu saber que sou guineense, eu não tinha contato. É nesse momento que encontro a família, tios, primos, e o reencontro com o meu pai, que era uma figura que tinha desaparecido. E quando ele me aparece à frente no aeroporto, é então que eu começo a chorar. Foi um momento muito intenso. 
Estive um mês na Guiné, entre um primeiro período em que não percebia muito bem se era de lá, ou não, apesar de toda a família e de eu entender perfeitamente o crioulo. Mas, entretanto, eu já não falava crioulo. E depois eu vinha de Macau com a ideia de que era preta, e ali já sou branca. Não pelo tom de pele, mas eu vinha com uma roupa XPTO de Macau, todas as tecnologias, etc. e só tinha 13 anos. Quando se decidiu que eu ia a Bissau, eu pensei que ia caber ali que nem uma luva. E isto não aconteceu. Então gera-se um conflito interno muito grande. Seria então de Macau? Ia ser um longo processo que eu tinha de digerir. Creio que esse é o primeiro momento em que começo a viver de facto as questões da identidade e em que comecei a fazer algumas perguntas. Mas eu tinha 13 anos e havia ali também o encantamento do momento mágico de pisar aquela terra, aquelas cores, cheiros, música, calor, a chuva. Lembro-me da chuva intensa com um calor imenso e toda a gente vinha para fora das casas, festejar. Eu queria ir e festejar, mas a minha avó impunha as regras do universo em que nós vivíamos em Macau, ou seja, eu não podia sair à rua, não podia andar descalça, tinha horários, coisas que o resto dos meus primos não tinham. E tive de ficar a ver aquela alegria da janela, foi um momento muito forte.

A Guiné ficaria sempre com o que guardei intensamente dessa visita: amor, a família e as raízes, não no sentido nacionalista, mas de enraizada de uma forma afetiva. Não que eu fosse viver para a Guiné por ser de lá, mas porque a Guiné passou a existir dentro de mim sob esta forma: afeto, memória e qualquer coisa de melancólico.

Voltei à Guiné em 2005 e depois em 2009 para visitar a família, mas também como artista, para o meu trabalho, mas já a partir de Portugal para onde, entretanto, tinha ido estudar Belas Artes, Design, no Porto. No primeiro ano, vim com a minha tia-avó, mas ela vivia em Braga e de novo comecei a minha adaptação, o reajuste à língua, embora eu tivesse estudado em português, não tinha a língua da rua, muito menos com o sotaque do Porto. Não foi complicado, mas não deixou de ser um processo em que, mais uma vez, uma pessoa fica muito exposta e, às vezes, a solução passa por nos tornarmos invisíveis, o mais discreto possível, não entrar em conflito com a vivência das pessoas que estão no seu dia-a-dia. Acabei por desistir do Design, fui viajar e regressei depois para fazer a licenciatura em "Som e Imagem", na Universidade Católica. Entretanto fui para a Alemanha, onde vivi dois anos e regressei a Portugal para fazer o mestrado. A Alemanha foi muito importante, vivi na Floresta Negra, e mais uma vez lá estive em adaptação, a aprender a língua, começar e a ajustar-me a uma forma de estar muito diferente. Tive momentos complicados, mas também foi um espaço marcante, evolutivo no sentido do que é que eu queria fazer.

Em 2009, quando fui à Guiné-Bissau, filmei muito na Guiné - Conacri e no Senegal, Mali e Burkina Fasso. Mas o meu olhar era mais de pesquisa na altura, estava a trabalhar sobre a dança e música africanas como pesquisa pessoal e como bailarina de dança africana. Era uma viagem antropológica, mas também importante do ponto de vista artístico. 
A minha primeira curta-metragem tem a ver com a mutilação genital feminina, trabalhei muito com mulheres. Foi o primeiro filme, foi um risco, porque o tema é exigente, mas foi também um impulso que era impossível não atender. E aí começo a questionar o meu desenraizamento, a minha identidade, os olhares e o olhar do outro, as relações económicas e políticas subjacentes já com uma intenção de dar forma a um trabalho que queria realizar. Foi no mestrado que comecei a escrever para o guião do filme "Mikambaru" ${ }^{2}$ em que os restos da colonização e da descolonização se manifestam sob a forma de estereótipos sem saída.

Os processos de descolonização são violentos e demora-se muito tempo a reencontrar a sua forma, pois não é uma questão de reencontrar uma forma, é inventar uma nova forma e tudo isso passa, de formas diversas, para as gerações seguintes. Em 2009, quando estive em Bissau e era tida como uma portuguesa, as pessoas vinham ter comigo com um discurso de que queriam que os portugueses voltassem. Pessoas de 30 ou 40 anos, portanto, que não tinham vivido o tempo colonial e, para mim, isto diz-me bem que a descolonização não foi bem-feita. Há qualquer coisa que está em conflito. São só algumas pessoas, mas para mim já seria suficiente alguém poder achar isto hoje para perceber que houve algo que não se passou bem. As estruturas políticas em Bissausempre foram muito frágeis, mas há qualquer coisa que não está mesmo bem, há qualquer coisa que não resultou, pois a corrupção e fruição do poder têm vindo a devorar o país pouco a pouco.

Hoje, e é muito recente em Portugal, vejo um olhar do português sobre si mesmo, uma avaliação mais autocrítica, autoanalítica, ou seja, um questionamento sobre a maneira como a história está a ser contada. Este repensar da história, este repensar das nossas relações com o outro, trazem, finalmente, alguns temas ao de cima e creio que fará com que muitos portugueses estejam a revisitar a sua maneira de se relacionar com os guineenses, com os africanos. Estamos a refletir sobre o racismo que existe na sociedade portuguesa, a analisar atitudes extremamente discriminatórias, estamos num caminho. Paralelamente temos, por exemplo, no Porto, um parque temático dos Descobrimentos - World of Discoveries. Temos de pensar como é que tudo isto se expõe hoje desta forma, no século XXI. Paralelamente ainda há uns tempos houve uma intensa polémica por causa da autorização de intervenção artística do Vasco Araújo no "Portugal dos Pequenitos", em Coimbra, e houve todo aquele impedimento. Alguém tem de nos ensinar a mudar o nosso olhar perante estes símbolos. Uma coisa é realmente olhar para eles e sentir orgulho, e alimentar certas ideias. Outra é começar a olhar e questionar e pensar no que fazer e como fazer para contemplar os outros lados da história.

A descolonização política não foi bem feita, mas a descolonização da mente é muito mais demorada e é também um processo de resistência. E há hoje uma série de artistas que estão a trabalhar nestes temas e que os trazem para o espaço público. É nesta linha que se insere o meu trabalho. Há, é claro em mim e no que faço, uma grande influência dos meus pais nas 
condições que me deram, mas também ideologicamente. Eu tenho a imagem de herói no meu pai. A figura do sábio, do intelectual, do professor. É, sem dúvida, a imagem do herói. E a figura de mãe, de mulher, porque essa figura inspira-me muito. Não com a ideia da beleza, mas a imagem da força, da luta. Sou filha e neta de mulheres que se viram em situações complexas, moldadas por uma história que é a nossa, e que é muito mais complexa do que as oposições tradicionais que se fazem entre colonizadores, colonizados. Foi uma época em que as pessoas foram chamadas a tomar decisões. Os meus pais tomaram decisões, comprometeram-se.

Mikambaru é um filme que reflete essas heranças em que há essa descrição do que é o reflexo de si no outro. E que há esta relação de interdependência. As personagens tomam decisões para se libertarem de certas heranças, fazem escolhas que geram conflitos intergeracionais e que geram vida.

Vanessa Fernandes foi entrevistada por Margarida Calafate Ribeiro e Mónica Silva, em Águeda, Portugal, em 5 de agosto de 2017. Vanessa Fernandes é cineasta.

Mais informações: https://vanfern612.com/

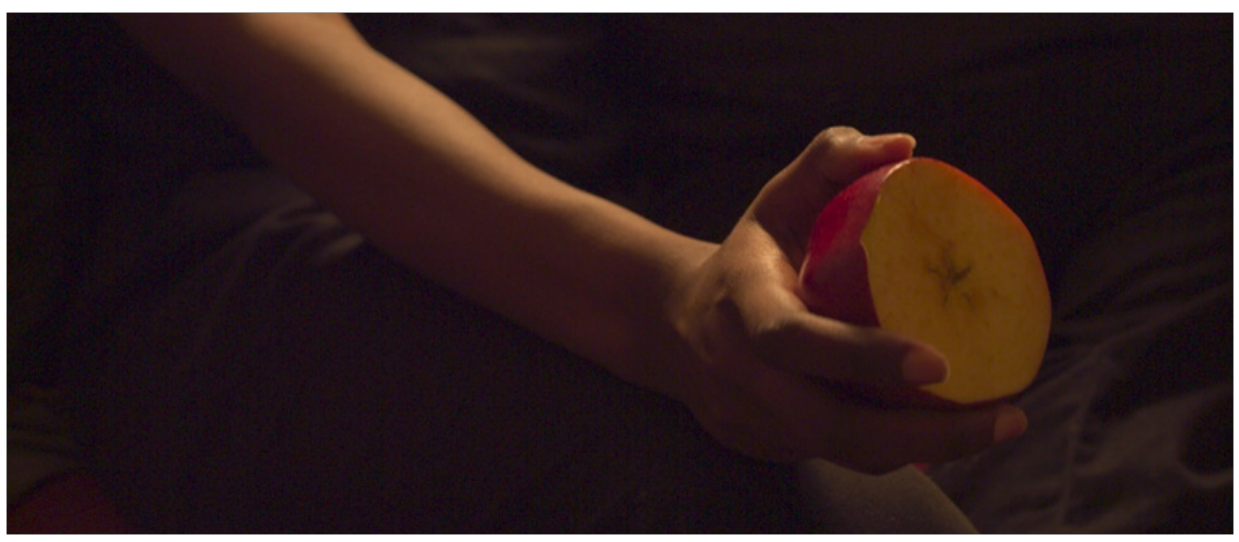

Imagem 7 - Mikambaru | 2016 | Vanessa Fernandes (cortesia da artista).

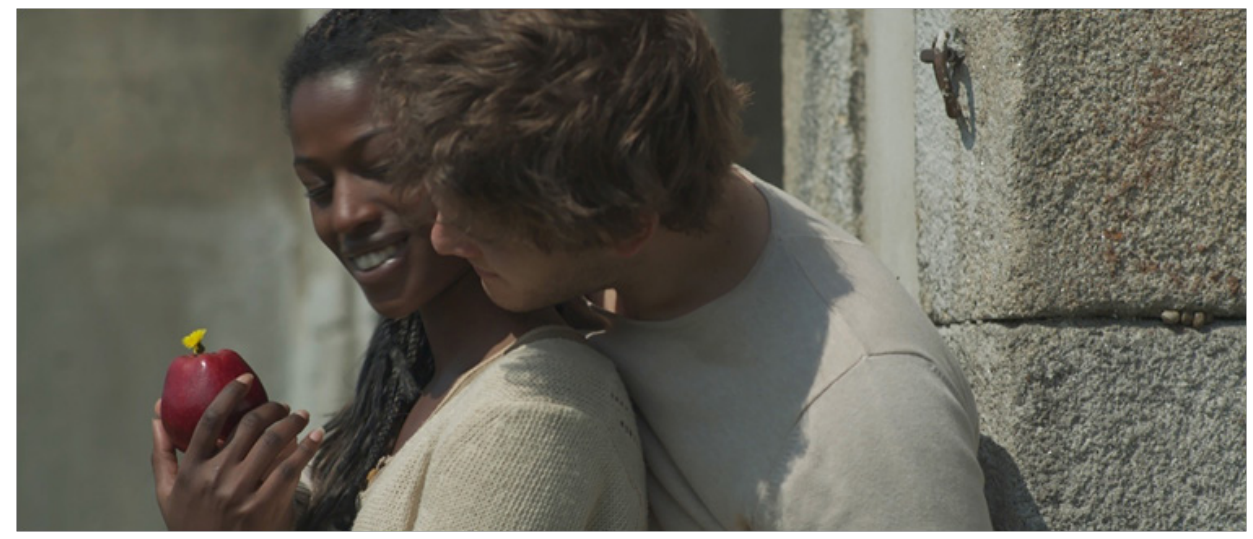

Imagem 8 - Mikambaru | 2016| Vanessa Fernandes (cortesia da artista). 


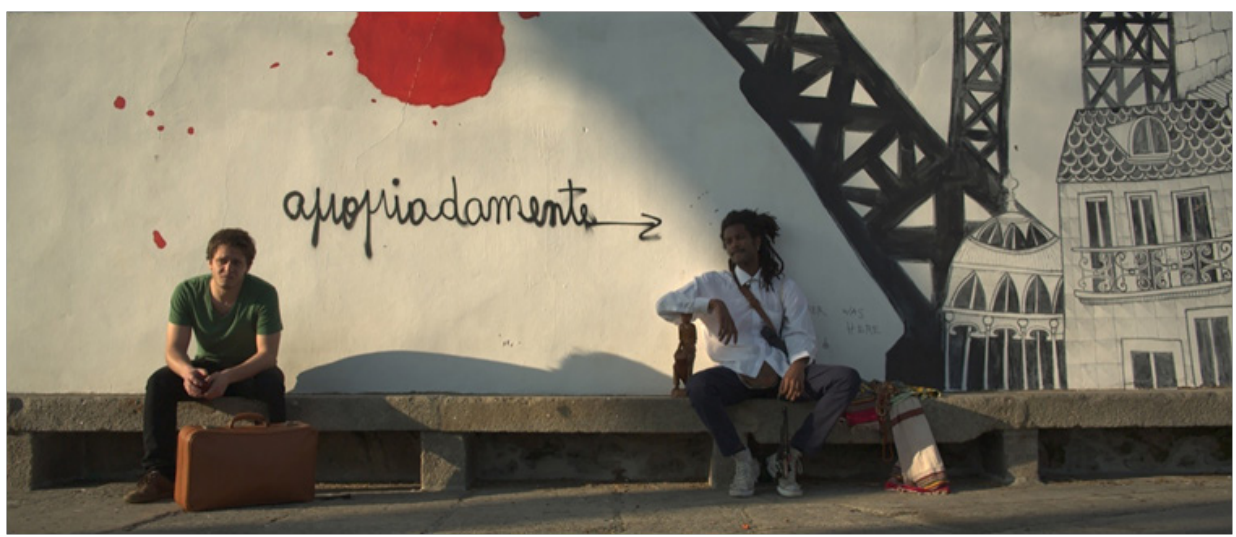

Imagem 9 - Mikambaru | 2016 | Vanessa Fernandes (cortesia da artista).

\section{JORGE ANDRADE}

\section{"Eu nunca construí essa ideia de paraíso perdido da infância"}

A minha família vivia no Chókwè, no Sul de Moçambique, onde os meus pais eram produtores de arroz e criavam gado, mas a minha mãe foi ter-me à maternidade, na antiga capital, Lourenço Marques, hoje Maputo. Nasci a 18 de maio de 1973 e vivi no Chókwè até 1977, ano em que viemos para Portugal. O meu pai era muito apegado ao seu arroz e às suas cabeças de gado, e os meus pais procuraram ficar a viver lá, como aliás os meus tios que nunca vieram para Portugal.

A família do meu pai é do Norte de Portugal, quase ao pé da fronteira com a Galiza, e a minha mãe é da ilha da Madeira. Tanto a família do meu pai como a da minha mãe eram famílias muito numerosas e extremamente pobres. A certa altura alguém, representante do governo, apareceu com uma proposta para a família do meu pai ir inicialmente para Angola. Poderia ser-lhes concedido um empréstimo, que pagariam com a produção que fossem desenvolvendo na terra que lhes fosse atribuída na colónia. Acabaram por não ir para Angola porque, entretanto, o navio que levava os emigrantes estava lotado, e foram na leva seguinte. Foi assim que foram para Moçambique, o meu pai teria uns 10 anos. Da parte da família da minha mãe aconteceu algo parecido. Foi lá que os meus pais se conheceram e casaram. Nós, a geração seguinte, seríamos quatro irmãos, mas a minha irmã morreu à nascença, e um dos meus irmãos morreu com um ano, com malária, estava a minha mãe já grávida do único irmão que tenho. Somos, portanto, dois irmãos.

Antes de casar com a minha mãe, o meu pai esteve na guerra e nas minhas pesquisas encontrei a caderneta militar dele, onde estavam averbadas duas fugas, o que para mim é um motivo de orgulho. Mas o meu pai pou- 
co falou, apenas dizia que a guerra tinha sido um tempo muito duro e foi provavelmente nessa altura que começou a desenvolver as úlceras nervosas que sempre teve. As minhas memórias são muito fugazes, imagens apenas ou histórias desse tempo que ouvi ao longo da vida.

O meu pai negociava e trabalhava, mas a minha mãe é que tomava conta da economia doméstica. E houve um episódio, sempre falado: tornou-se uma história familiar. Uma vez o meu pai estava fora e a minha mãe, que é muito católica, acabou por dar bastante dinheiro ao padre que andava a angariar fundos para a construção ou para a recuperação da igreja. $\mathrm{O}$ meu pai, quando soube, ficou furioso e passou ele a tomar conta de tudo. Então a minha mãe preparava tudo para o pequeno-almoço, o meu pai sentava-se, mas não havia nada para comer. Saía furioso e, entretanto, a minha mãe dava-nos o pequeno-almoço. Ao almoço o meu pai vinha e tínhamos a mesma cena. Durou dois ou três dias, até que o meu pai cedeu. Era o que a minha mãe me contava. Lembro-me de muito pouco, infelizmente. Confundo se me lembro ou se é uma elaboração do que me contam, das fotografias que criaram as imagens que tenho.

Voltei a Moçambique pela primeira vez em 2010, para fazer uns workshops e completar uma pesquisa que estava a fazer. E o meu pai, pelo telemóvel, orientava-me nas direções das ruas. Mas eu não tinha memória nenhuma. Lembro-me vagamente de uma vizinha a molhar pão em água gelada e de me dar, lembro-me do chão muito quente; lembro-me de matar uma cobra. Quando voltei a confrontar-me com o local, em 2010, já tinha alguma consciência histórica sobre a colonização e senti-me bastante envergonhado pelo quanto eu desconhecia da história de Moçambique. Foi uma sensação estranha pois, ao mesmo tempo que estava a voltar a um local que eu desconhecia, esse tinha sido o local onde os meus pais tinham feito parte da sua vida e que representava, para eles, uma ideia de felicidade. E os meus tios continuavam lá e, portanto, a "fotografia" tornou-se muito mais tridimensional. Mas eu nunca construí essa ideia de paraíso perdido da infância. Como nunca tive essa imagem, nunca a fui desfazendo.

Fui a Moçambique mais duas vezes e uma das vezes com o meu marido, que também nasceu em Moçambique. Mas é uma história completamente diferente. Os seus pais eram professores, a mãe professora de Biologia e o pai professor universitário na área da Engenharia. São outras vidas, outras memórias. Andámos em Maputo com um mapa de Lourenço Marques a ver as ruas e as casas e ele lembrava-se do espaço.

Para mim hoje Moçambique é um misto. É um local onde eu gosto bastante de estar, sinto uma afinidade com as pessoas que conheci lá. Sinto... não é um sentimento de culpa, mas há ali uma coisa qualquer que me é difícil. Uma das vezes em que estive em Moçambique, Portugal estava no Europeu de futebol e ganhou. Coincidiu com as minhas pesquisas em que tinha estado a ler sobre todas as atrocidades que nós lá fizemos. Mesmo a ideia de alguma inocência em relação aos portugueses que tinham ido 
para lá muito pobres, em que eles próprios também eram instrumentalizados, como os meus pais, ia-se esbatendo à medida que avançava com as minhas leituras: coisas atrozes que fizemos e que não foram poucas. $\mathrm{E}$ naquele restaurante, no momento em que Portugal ganhou o campeonato e os moçambicanos começaram a cantar e a dançar festejando a vitória, no fundo sobre um imaginário que partilhamos, fiquei extremamente perplexo. É como eu saber tudo e não conseguir deixar de acreditar em Deus! E esta referência não é inocente.

A devoção religiosa da minha mãe foi muito importante na nossa formação. Ainda hoje sou cristão, andei na catequese, fiz a primeira comunhão e o crisma, ajudava o padre na missa e confessava-me. Ia com o meu pai, a minha avó, o meu irmão e a minha mãe, e eu queria ser sempre o primeiro para depois ir brincar para a rua. Confessava-me com o padre Agostinho, que era de Tires. Eu contava sempre os mesmos pecados e o padre dizia sempre mais ou menos a mesma coisa. Rezava as minhas penitências e ia brincar. A minha avó tinha-me advertido que havia pecados que só a nós diziam respeito e que o padre não tinha que saber. Assim, e de acordo com a minha avó, eu deveria passar em frente ao altar e dizer - "Meu Deus perdoai os meus pecados esquecidos e lembrados que ao pé do confessor não foram bem confessados" - e dava uma penitência a mim próprio. Maschegou uma Páscoa em que o padre Agostinho estava doente e veio um padre de São Domingos de Rana. Eu contei os pecados consentidos e o padre deu-me uma imensa penitência. Tive de confessar que dizia sempre os mesmos pecados e que esta penitência era enorme comparada com o habitual, e que assim os meus pais iriam pensar que eu tinha feito imensas coisas más. Até que o padre disse que eu podia rezar a penitência habitual. Fiquei incomodado com aquela negociação e nunca mais me confessei, mas a religião está inscrita em mim. Ainda fui para os protestantes, mas ainda era pior e hoje mesmo quando digo que sou agnóstico, ou ateu, quando fico a sós comigo peço logo desculpas a Deus. Tenho os sacramentos todos, só falta a extrema-unção! A questão colonial é um pouco assim também, está inscrita em nós, condicionou completamente a vida dos meus pais e consequentemente a minha.

O regresso dos meus pais em 1977 impôs-se, de acordo com o que o meu pai conta. Os meus pais não tinham formação política, mas cresci com o meu pai a dizer "Eu não sou comunista, mas ai de nós se não fossem eles!". Mas ele próprio não se conseguiu habituar ao novo regime. Em Moçambique o meu pai tinha as suas terras e, depois da independência, os soldados da FRELIMO levavam-no para trabalhar noutras terras e isso fazia-lhe imensa confusão: deixar as suas terras, o seu arroz e ir para outro lado, trabalhar num pedaço de terra que não era dele. Tentava esquivar-se, mas era difícil manter o seu negócio no novo enquadramento político moçambicano. Entretanto outros vizinhos tinham saído e havia novos vizinhos moçambicanos com quem os meus pais tinham alguma relação, mas houve um episódio em que atacaram a casa, estavam a tentar arrombar a porta e a minha mãe dentro de casa connosco muito pequenos. Foi decisivo para 
voltarmos. Os meus pais trouxeram um grande contentor, feito em madeira, onde puseram o que conseguiram trazer e, para trazer dinheiro, a minha mãe fez bainhas em todas as roupas para meter moedas. A quantidade de dinheiro que deixavam trazer era muito reduzida e afinal o dinheiro já nem valia nada. Ainda estão lá em casa as moedas, num saquito.

Quando chegámos não tínhamos sítio para viver. Fomos para o Vale do Jamor, onde havia um grande bairro todo feito em madeira. Era um bairro construído ou improvisado para receber os retornados. Ficámos lá, inicialmente a dividir um quarto com uma outra família, e depois acabámos por ficar com um quarto só para nós. Tínhamos umas casas de banho públicas e havia um refeitório. Durante uns dois anos, o contentor que tinha trazido as nossas coisas ficou à porta daquele pré-fabricado e eu brincava muito com os meus amigos lá dentro onde estavam coisas que não cabiam na casa, inclusive umas grandes seringas metálicas que eram para vacinar o gado - totalmente inúteis - mas que os meus pais também tinham trazido.

Naquele bairro, havia retornados, população africana que tinha vindo para Portugal durante aquele período e havia, surpreendentemente para mim, os timorenses, que estavam na parte superior do bairro, já a caminho de Linda a Velha. Eram condições muito precárias, porque o bairro estava mesmo ao pé do rio Jamor, com esgoto a céu aberto, as margens cheias de lixo. Os meus pais foram trabalhar na cozinha, onde se faziam as refeições para as pessoas que ali moravam. Mais tarde o meu pai foi trabalhar para o Estádio Nacional, a minha mãe ficou empregada a dias, e começou a fazer a $4^{\text {a }}$ classe, que o meu pai já tinha feito mais cedo. Saí desse bairro com sete anos, portanto, ficamos lá três anos, fiz lá a minha primeira classe. Fomos depois para o Bairro das Faceiras, entre Carcavelos e Tires. Eram casas de renda baixa atribuídas a pessoas que tinham vindo de África, a maioria africanos - angolanos, moçambicanos, cabo-verdianos, não me lembro de guineenses, nem de são-tomenses - e vivi aí até aos 17 anos. Lembro-me, nesse período, de que as pessoas não olhavam com muita simpatia para os retornados: achavam que tínhamos estado a enriquecer em África e agora ainda tínhamos casa enquanto essas pessoas, com certeza, não tinham estas casas. Identificavam-nos pela roupa, eu tinha um fato amarelo e quando entrei na escola era "o solinho", porque na altura também era louro. Era pela roupa que éramos identificados e por certos hábitos. Lembro-me que, quando a minha mãe ia de manhã comprar pão, punha as moedas no meio da nota e dobrava a nota para não perder o dinheiro e isso parece que era uma coisa típica de retornados. Os meus pais lidaram bastante bem com o drama que possivelmente viveram: vivíamos em péssimas condições, mas aquilo era a nossa realidade e reagiram. O meu pai teve uma oportunidade de ir para a Argentina criar gado e ficou muito animado. Era o que ele sabia e gostava de fazer. Chegámos até a comprar as passagens. Mas, entretanto, o meu avô tinha falecido e a minha avó, mãe da minha mãe, veio viver connosco e fez uma enorme pressão para não irmos. Dois dias antes de partirmos teve uma crise, argumentando que não queria voltar a sair do seu país, que se 
fosse para sair do seu país preferia morrer. E ficámos. O meu pai demorou muitos anos a perdoá-la. Na verdade, até ela morrer. Os meus pais nunca se lamentaram e, ao contrário da minha mãe, o meu pai de vez em quando dizia que gostava de voltar a Moçambique.

O meu percurso escolar foi regular, exceto eu ter enganado a professora da $1^{\text {a }}$ classe em relação a saber ler. Eu decorava os textos. Na segunda classe, fui apanhado e depois das aulas ficava sempre com a professora, eu e a Elisabete, que também não sabia ler. Depois de saber ler, tive sempre boas notas. Havia poucos africanos na escola: o Odemiro e o Adelino, que era um rapaz com quem eu ia sempre para a escola, morávamos perto. Mais tarde fomos para o liceu, mas andei em várias escolas. Entediava-me estar sempre no mesmo sítio, os mesmos colegas, os mesmos professores e, portanto, ia mudando.

No $10^{\circ}$ ou $11^{\circ}$ ano, tive uma professora de história que foi bastante importante. Ela ia muito além dos manuais escolares, falávamos sobre a colonização e a descolonização, e era muito criativa com os trabalhos. Eu estava sempre à procura de oportunidade para fazer outro tipo de trabalhos e fiz um filme, com uma colega que tinha vindo do Zaire e que tinha uma câmara de filmar. Fizemos um filme sobre os "Descobrimentos", organizávamos saraus artísticos, fazíamos festas e teatro com a ajuda do eletricista da escola que era técnico do teatro nacional.

No $12^{\circ}$ ano, fui para o programa de intercâmbio do American Field Service, em que a nossa família recebia um estudante estrangeiro e nós íamos viver durante um ano com outra família. Fui para os Estados Unidos, mas na verdade queria ir para o Japão. Estive em Connecticut, no meio da floresta, em casa de gente rica, e foi uma estadia importante para me decidir a ir para teatro. Na escola havia um grupo de teatro, participei num musical e assim densifiquei a experiência de teatro que tinha tido com um grupo de teatro de Cascais. Claro que quando anunciei em casa esta pretensão foi um desgosto generalizado, pois eu tinha boas notas e o meu pai tinha outro destino para mim, mas acabou por aceitar. Chumbei nas primeiras provas, o que foi um desastre, estive no Chapitô um ano e depois entrei no Conservatório, Escola Superior de Teatro e Cinema. Na altura fiz o bacharelato, mais tarde a licenciatura. Um dos períodos importantes na minha formação foi o curso de criatividade e criação artística da Fundação Gulbenkian, onde "voltei" de alguma forma ao Ultramar, com "Philatélie". A ideia era construir um espetáculo a partir do primeiro selo da minha coleção e do último, que era de Saddam Hussein. Na altura os americanos estavam a fazer sua perseguição. Mas acabou por ser algo diferente. Talvez ainda por causa da minha professora de história, fiz um espetáculo em que se recriava a chegada dos portugueses às terras dos japões.

O espetáculo "Moçambique" ${ }^{3}$, de 2016, faz parte da minha história pessoal. Parte do convite que o meu tio me fez, quando o visitei em Moçambique: queria que eu ficasse lá a viver com eles, a cuidar dos negócios, o 
que me deixou espantado. Eu era ator e o negócio dos meus tios no Chókwè eram bombas de gasolina e arroz. Essa tinha sido a vida deles ali nos últimos 30 anos. O desafio do espetáculo foi pensar a minha biografia como se eu tivesse ficado a viver em Moçambique. E tive de inventar uma vida dentro da história de Moçambique com todas as suas vicissitudes políticas, a história da Guerra Fria e as negociações internacionais de Oeste a Leste para exportarmos o tomate. Essa era a diferença, vendia tomate e não arroz. Fui consultando muitos livros, vendo muitos filmes, lendo muitas biografias de quem tinha ficado a viver em Moçambique e fiz literalmente um mergulho na minha própria vida e da minha família para começar a escrever o texto. Não são memórias minhas, são memórias ficcionadas. O espetáculo conta a história de um indivíduo que, tendo regressado muito novo de Moçambique e tendo perdido grande parte da sua história, quando já está na meia idade resolve voltar atrás para revisitar aquele país a partir de um pretexto. E olha para aquela história com estranheza, mas também com uma enorme liberdade, que só é possível a quem não a domina. Assim toda a história que eu conto é verdade dentro da minha vida ficcionada. É uma história ficcionada da parte da minha família que ficou lá, pois como me explicou a minha tia "se nós deixamos isto eles roubam tudo, e roubam o dinheiro". E depois na vida real o meu tio foi assassinado e a minha tia lá continua.

O espetáculo é situado em Moçambique, mas este é um tema europeu. O que restou do colonialismo e como é que os regimes no pós-independência articularam esta herança com os novos tempos dos jovens países? E não vai adiantar nada andar a dizer, que os belgas foram piores "Olha o Leopoldo!", ou que ainda piores foram os ingleses... Fomos um continente colonizador e mesmo nós portugueses, apesar de sermos um pouco periféricos em relação a esta Europa Ocidental, temos esse passado, não fomos um colonizador com um " c" minúsculo por causa disso. E essa relação continua ainda hoje, com o que ainda são as marcas das heranças coloniais nesses países e no racismo com que, por exemplo, em Portugal tratamos os afrodescendentes. Não se trata de recuperar um passado mas de, através de uma memória-ficção, transformá-lo, como temos de transformar o presente. O espetáculo é muito irónico e as receções têm sido diversas, mas o que me interessa não é saldar dívidas ou fazer uma grande reflexão sobre o assunto como as próprias dos estudiosos. Para mim, enquanto artista, interessa-me ver como é que o espetáculo consegue gerar um outro patamar de entendimento entre nós e o público que nos está a ver.

Não me interessava nada fazer um statement que pudesse gerar uma discussão sobre o que foi a nossa colonização, a descolonização ou a independência. Mas o que acontece é que através da ficção as pessoas podem ter uma ideia do que foi aquela realidade. Tivemos reações desde um grupo de moçambicanos na plateia a desfraldar a bandeira de Moçambique e a vir tirar fotografias connosco, até aos programadores franceses, muito sérios, que consideraram que todo o humor que era utilizado em relação a uma história que é trágica era muito suscetível de ser mal-entendido, como uma 
espécie de paródia à história dos outros e, portanto, pouco ética. Mas, na verdade, na peça, se alguém é ridículo somos nós próprios que estamos a tentar mudar a história de um país, em uma hora e um quarto, na esperança de não sermos culpados. E, portanto, tivemos de voltar atrás na história, para podermos ter dinheiro para contratar alguém para nos defender e tudo isto só é possível no teatro, na ficção: porque na realidade infelizmente isso não se pode fazer. É um espetáculo festivo e atento, cheio de músicas de trabalho e de dança, não há nada de catarse ou de redenção: não é essa a minha linguagem. Mas há uma interrogação.

Hoje há uma segunda geração de africanos que vivem cá e que conseguem lidar com as suas referências originais de uma forma muito pulsante, muito contemporânea e presente, e isso é um caminho.

Jorge Andrade foi entrevistado por Margarida Calafate Ribeiro e António Pinto Ribeiro a 1 de novembro de 2017, no Centro de Estudos Sociais, nas instalações de Lisboa. Jorge Andrade é ator, encenador e co-diretor da companhia Mala Voadora.

Mais info: https://malavoadora.pt/

O espetáculo “Moçambique” por Jorge Andrade: https://www.youtube.com/watch? $\mathrm{v}=\mathrm{khm} 3 \mathrm{GbulMI} 0$

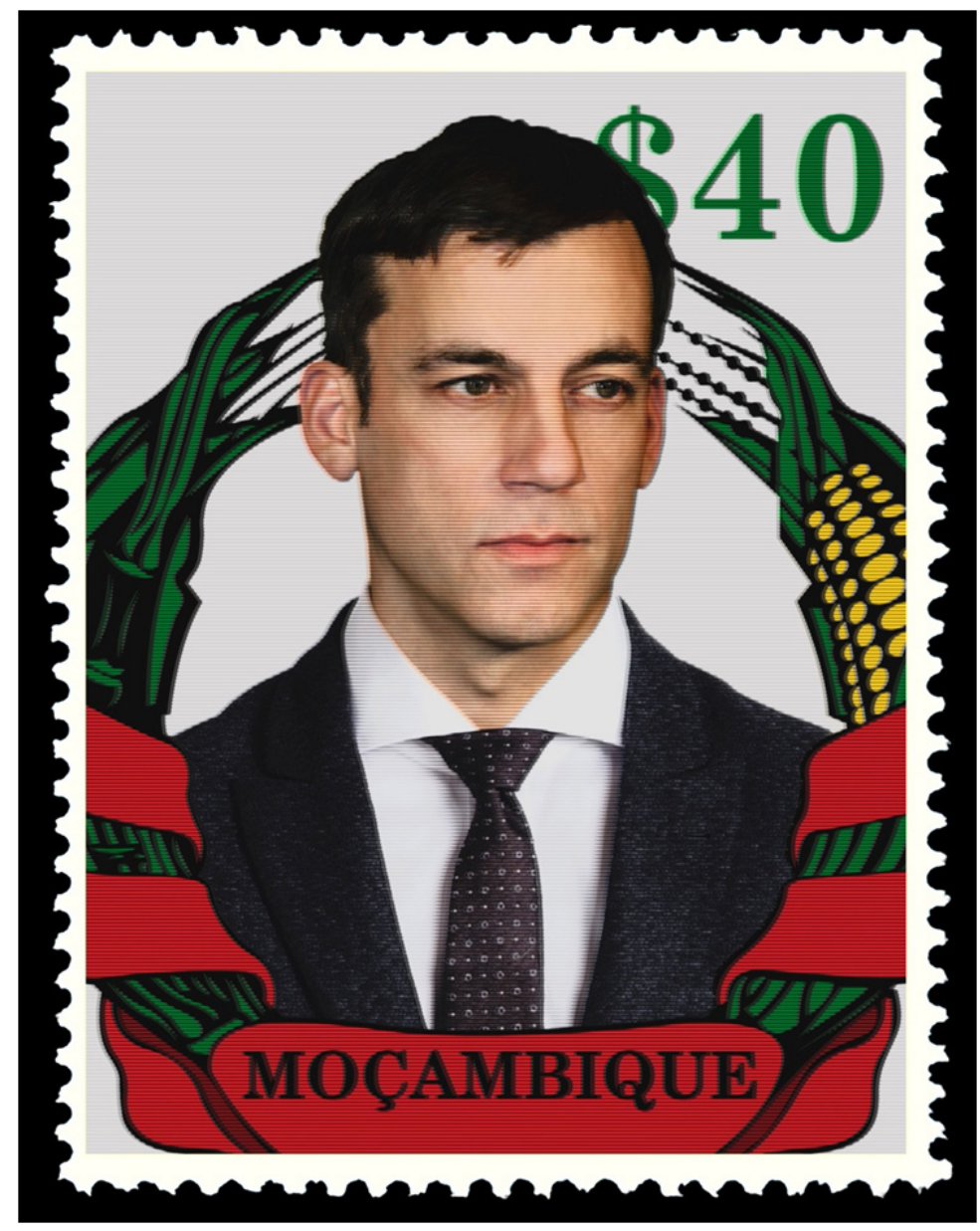

Imagem 10 - Moçambique| 2017 | cortesia da Mala Voadora. 


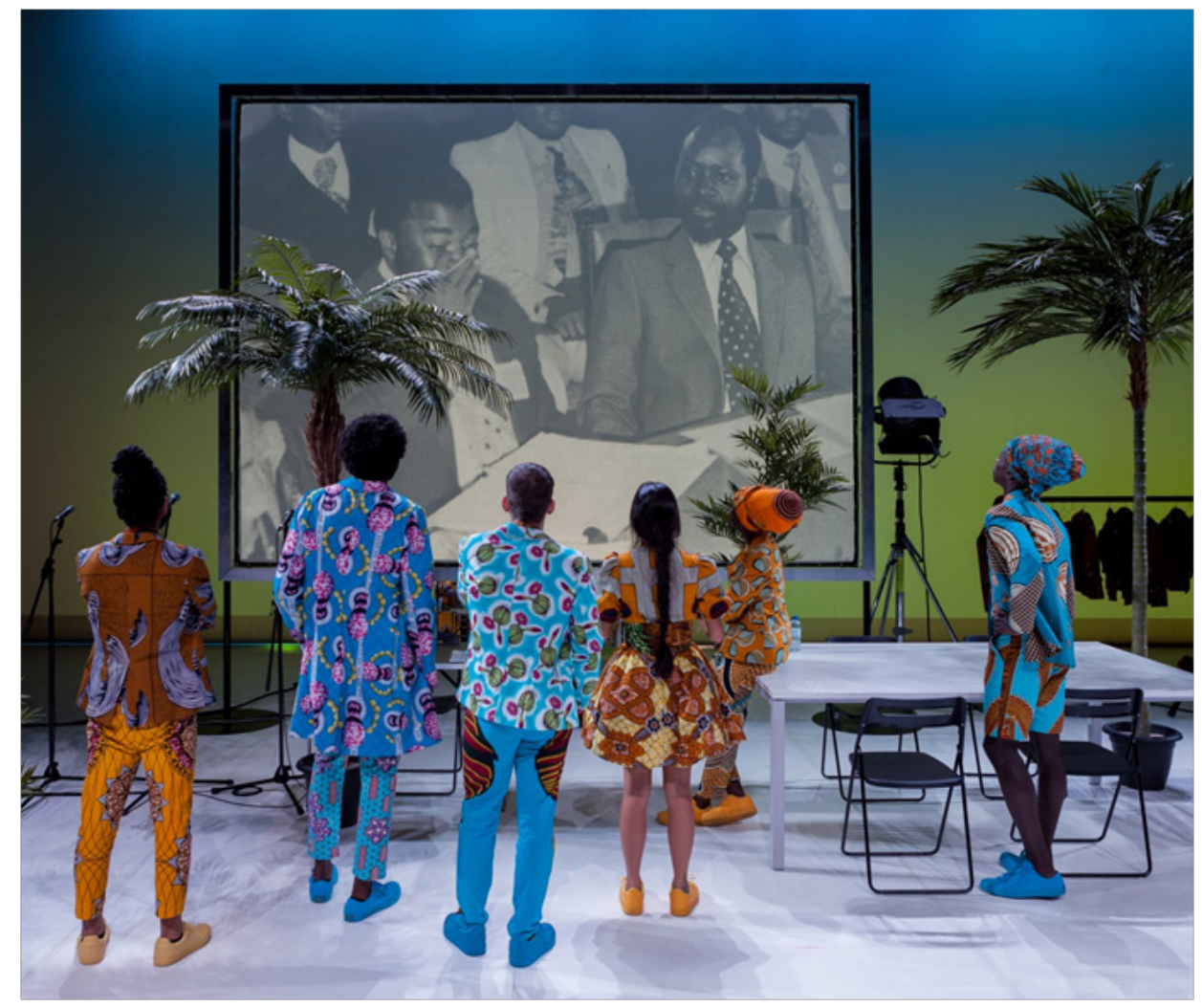

Imagem 11 - Moçambique | 2017 | cortesia da Mala Voadora.

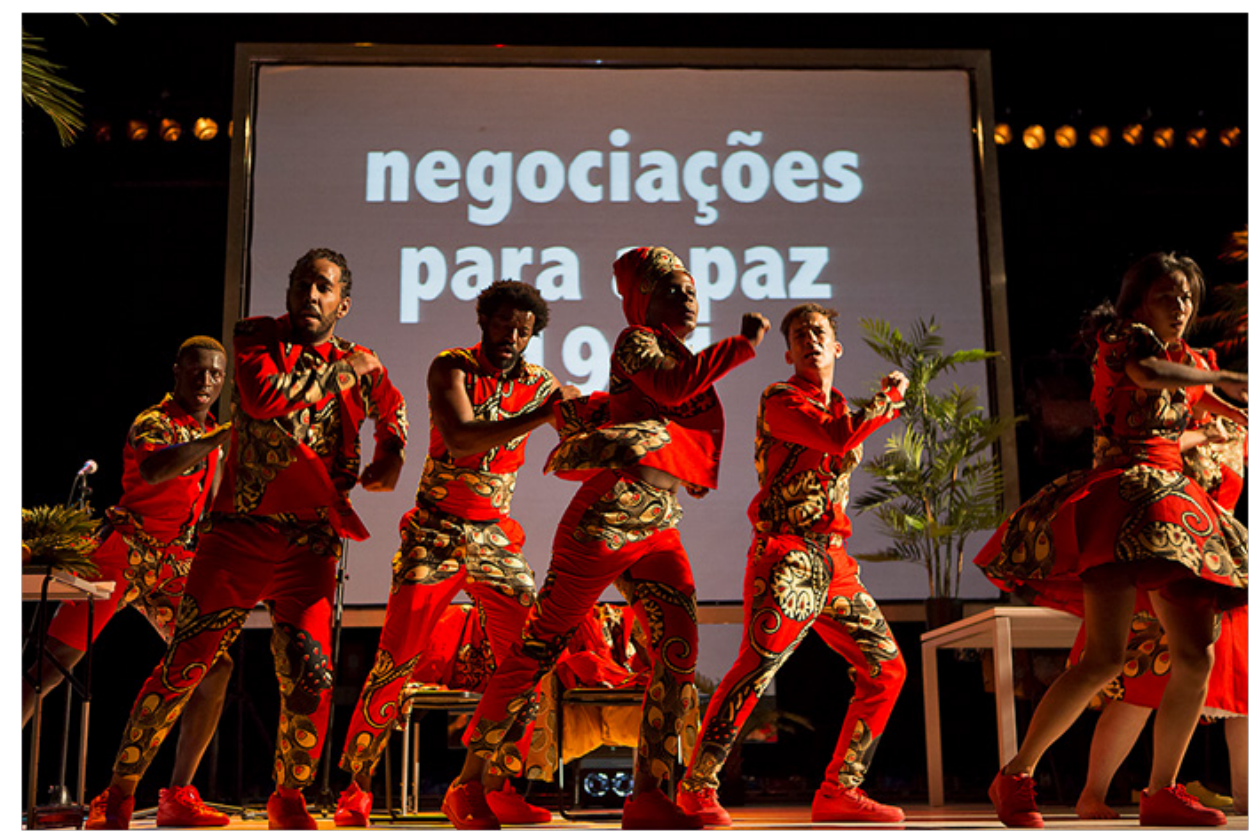

Imagem 12 - Moçambique | 2017 | cortesia da Mala Voadora. 


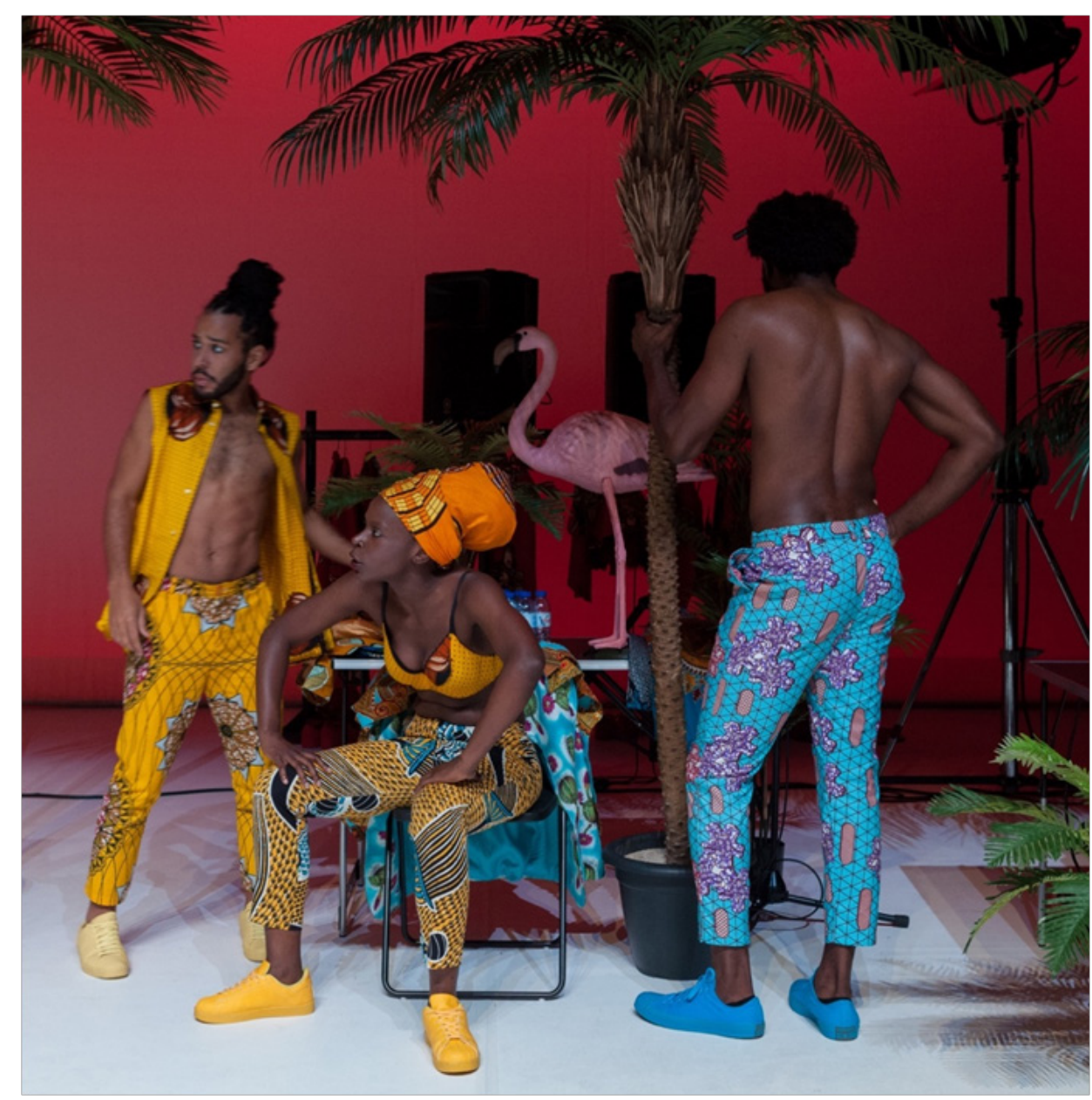

Imagem 13 - Moçambique | 2017 | cortesia da Mala Voadora.

Recebido para avaliação em 01/07/2021 Aprovado para publicação em 04/08/2021

\section{NOTAS}

1 Este artigo resulta do trabalho desenvolvido pelo projeto MEMOIRS - Filhos de Império e Pós-memórias Europeias, financiado pelo Conselho Europeu para a Investigação (ERC) no quadro do Horizonte 2020, programa para a investigação e inovação da União Europeia (contrato n 648624), e sediado no Centro de Estudos Sociais da Universidade de Coimbra e coordenado por Margarida Calafate Ribeiro.

Margarida Calafate Ribeiro e Fátima da Cruz Rodrigues são investigadoras do Centro de Estudos Sociais da Univerisdade de Coimbra. ORCID: https://orcid.org/ 0000-0003-48651761; https://orcid.org/ 0000-0001-9578-8774

2 “Mikambaru” (2016), filme acessível em https://vimeo.com/282461138

3 Sobre o espetáculo ver https://malavoadora.pt/espectaculos/mocambique_392.html (consultado a 25.02.2014). 